\title{
Mirosława Hordy
}

\section{Rosyjskie wyrażenie не судьбa i jego polskie odpowiedniki}

Aвstract: Hordy Mirosława, Rosyjskie wyrażenie не судьба i jego polskie odpowiedniki (The Russian Expression не судьба and Its Polish Equivalents). "Poznańskie Studia Slawistyczne" 19. Poznań 2020. Publishing House of the Poznań Society for the Advancement of the Arts and Sciences, Adam Mickiewicz University, pp. 349-362. ISSN 2084-3011.

The subject of the article is a comparative analysis of the Russian expression не судьба кому-л. and its Polish equivalents. In the ethno-cultural aspect, it describes one of the Russian key ideas the concept of $S U D^{\prime} B A$. The special status of the discussed unit is evidenced by: the synthetic form and the inability to express its content in the same simple way in another language, the non-assertive type of meaning and informality. The analysis of lexicographic and corpus sources shows that the closest synonyms of the Russian predicate are Polish sentence phrases, coś nie było sadzone komuś and taki los that shows semantic and pragmatic differences. The devaluation of the importance of the Russian unit observed in recent uses consists in changing the attitude of regret towards unfavourable events into a sense of relief and its relation to "light" and ordinary events. This meaning corresponds to Polish - taka już czyjaś uroda.

KeYwords: key idea; LOS; СУДЬБА; semantics; pragmatics; interlingual equivalents

Różnice idei kluczowych LOS і СУДЬБА w języku polskim i rosyjskim zostały opisane przez Annę Wierzbicką (1991) i stały się przyczynkiem licznych studiów oraz polemik (cf. Булыгина, Шмелёв, 1997; Шмелёв, 2002; Апресян, 2006а; Апресян, 2006; 2008; Bartmiński, 2000). Status takiej idei, jak stwierdza Jurij D. Apresjan, jest tym silniejszy, im więcej środków wyraża ją w danym języku, im większa jest ich różnorodność (szczególnym wskaźnikiem są tu znaczenia gramatyczne) i im większa jest grupa języków, które nie są w stanie wyrazić jej w tak prostej formie, jak wyraża ją język, dla którego jest ona ideą kluczową. Silne etniczne nacechowanie jednostki językowej występuje wtedy, gdy idea wyrażona prostym środkiem w jednym języku, może być wyrażona w innym tylko poprzez opis, tj. przez jednostki złożone - wyrażenia i zdania. Słabe 
nacechowanie etniczne istnieje, gdy ideę tę wyrażają środki podobnie proste jak w języku bazowym z zastrzeżeniem, że w języku bazowym środki te mają status zgramatykalizowany lub częściowo zgramatykalizowany (Апресян, 2006a, 34-36). Tego typu jednostką etnolingwistyczną jest rosyjskie wyrażenie не судьба кому-л. Celem analizy jest opisanie polskich synonimów tego wyrażenia oraz kontekstów ich użycia, co jednocześnie wskaże różnice i podobieństwa reprezentowanych przez nie pojęć.

$L O S$ i СУДЬБА w obu językach odwołują się do determinizmu życia ludzkiego przez czynniki zewnętrze wobec człowieka, na które nie ma on wpływu. Źródłem różnic między tymi pojęciami, jak wskazuje A. Wierzbicka, jest już ich etymologia. Polski leksem los jest zapożyczeniem z języka niemieckiego. Pochodzi od pragermańskiego los (loos) oznaczającego każdy przedmiot do losowania czy samą czynność losowania i wprost odwołującego się do czynności magicznych wróżenia, przepowiadania przyszłości (Duden 7, 409). Rosyjski leksem судьба wywodzi się natomiast od czasownika mentalnego cydumb i związany jest z pojęciami SACD i SECDIEGO (Wierzbicka, 1991, 11) .

Eksplikacja znaczeń tych leksemów przeprowadzona przez uczoną pokazuje, że oba zawierają identyczny komponent znaczeniowy mówiący o tym, że z różnymi ludźmi dzieją się w życiu różne rzeczy. Za równoważny, ale nie tożsamy, element znaczeniowy uznać można brak władzy człowieka nad życiem w ogóle występujący w leksemie polskim i brak władzy człowieka nad swoim własnym życiem obecny w rosyjskim. LOS obdarza człowieka zdarzeniami dobrymi i złymi i czyni to nierównomiernie, СУДЬБА zaś jest jedną całością zdarzeń dobrych i złych. Istotną różnicą tych pojęć jest według Wierzbickiej postawa człowieka wobec życia - aktywna w polszczyźnie ${ }^{2}$ oraz pasywna, zachęcająca do pokornego przyjęcia i pogodzenia się z nim w ruszczyźnie, co wzmacnia przywołanie idei decydującego sędziego (Вежбицка, 1994, 92-97).

Polskie pojęcie LOSU Wierzbicka uznaje za neutralne wobec rosyjskiego СУДЬБА, tj. ani dobre, ani złe, w odróżnieniu od języka angielskiego,

${ }^{1}$ Leksem los występuje w polszczyźnie od XIV wieku w znaczeniach: 'rzecz do losowania', ‘bilet loteryjny', 'przeznaczenie, przypadek, fatum', 'bieg wydarzeń' (Długosz-Kurbaczowa, 2008, 363; cf. Bańkowski, 2000, 63; Boryś, 2005, 290).

${ }^{2}$ Polski $L O S$ nie ma elementów poddania, rezygnacji czy pokornej akceptacji jak rosyjska СУДЬБА (Wierzbicka, 1991, 11). 
w którym występują dwa leksemy: destiny o znaczeniu pozytywnym, wskazujący, że życie ma sens czy wartość, i opozycyjny względem niego fate o znaczeniu negatywnym, który wskazuje, że życie jest złe lub bezsensowne (Wierzbicka, 1991, 8).

Rewizji tej klasycznej w językoznawstwie charakterystyki pojęcia LOS dokonuje Jerzy Bartmiński (2000), zwracając uwagę na funkcjonowanie w polszczyźnie dwóch równorzędnych pojęć - LOS i DOLA. Pierwsze uznaje badacz za pojęcie pozytywne, podobnie jak łacińska fortuna, drugie - za negatywne, analogiczne łacińskiemu fatum. Podział taki pozwala uznać polski leksem los za odpowiednik angielskiego destiny, a leksem dola za odpowiednik angielskiego fate. Różnice między pojęciami uwarunkowane są według badacza sferą społeczną ich powstania.

Pojęcie LOSU konstruowane jest przez człowieka wolnego od przeświadczenia o zewnętrznej detreminacji własnego życia, odważnego i aktywnego, który wierzy w możliwość wpływu na swoją egzystencję, pojęcie $D O L I$ - przez człowieka uznającego ograniczenia swojej kondycji i godzącego się z własną sytuacją życiową, która dana mu była z zewnątrz i której nie może zmienić. Reprezentantem pojęcia $L O S U$ był w polskiej kulturze szlachcic, później powstaniec, legionista, dysydent, inteligent znajdujący swoje uosobienie w ideale śmiałka, szaleńca, zuchwałego ryzykanta w etosie powstańczym; odzwierciedleniem pojęcia DOLI - chłop, z czasem człowiek z ludu, plebejusz, współcześnie zaś tak zwany szary, prosty człowiek $^{3}$ (Bartmiński 2000). Bartmiński wyprowadza w ten sposób znaczenie polskiego pojęcia $L O S$ poza spektrum zdarzeń determinowanych zewnętrznie w życiu człowieka i wiąże je z przekonaniem o determinacji wewnętrznej i możliwości kształtowania ich przez człowieka. Tym samym polska DOLA bliższa jest rosyjskiemu pojęciu СУДЬБА ze względu na pasywność doświadczającego jej człowieka i niemożność przezwyciężenia

${ }^{3}$ Bartmiński stwierdza żywotność koncepcji DOLI w zjawisku socjokulturowym w ,chłopieniu” polskiego społeczeństwa, a także w procesie polskiej transformacji ustrojowej, której dało początek zwycięstwo Solidarności - ruchu z natury swej ludowego. Ponadto pojmowana plebejsko DOLA pozostała wśród tej części społeczeństwa, która nie partycypowała $\mathrm{w}$ profitach transformacji ustrojowej. Tu również nasuwają się paralele z geopolitycznym podziałem, tym razem samej Polski na Polskę A - zachodnią i Polskę $\mathrm{B}-$ wschodnią. 
istniejącego ładu społecznego ${ }^{4}$. Wydaje się, że wskazane źródło społeczne pojęcia DOLA uzasadnia jego dwojaką negatywność: pasywność i brak wiary w możliwość zmiany swego losu oraz zły i trudny charakter doświadczanych zdarzeń. Negatywność tę ukazuje również zakres łączliwości leksemu, por. chłopska, człowiecza, ludzka, psia, sieroca, ciężka, zła dola; dola chłopa, emeryta, emigranta, poety, ucznia, żolnierza; Indian, Murzynów; ulżyć czyjejś doli (WSJP). Czy jednak polski LOS jest pojęciem odnoszącym się tylko do pozytywnych zdarzeń życia?

O specyfice etnicznej rosyjskiego wyrażenia не судьба кому-л., które opisała Walentyna J. Apresjan (Апресян, 2006; 2008), stanowią: manifestacja w nieasertywnych komponentach wypowiedzi, brak możliwości tłumaczenia na inne języki w podobnie prostej formie oraz częściowo zgramatykalizowany status. Wyrażenie to nie jest zaprzeczeniem rzeczownika rodzaju żeńskiego cудьба ani semantycznie, ani składniowo. Nie oznacza pojęcia przeciwstawnego leksemowi судьба - *несудьба, pol. los - *nielos, analogicznie do par счастье - несчастье, доля - недоля, pol. szczęście - nieszczęście, dola - niedola, fart - niefart. Na jego predykatywny charakter wskazuje funkcja syntaktyczna formy przeczącej не. Jest predykatem o znaczeniu stanu, tożsamym znaczeniowo $\mathrm{z}$ wyrażeniem не суждено i gramatycznie utrwalonym zgodnie z paradygmatem rosyjskich konstrukcji celownikowo-bezokolicznikowych. Jednak funkcję predykatu w takich konstrukcjach regularnie pełnią krótkie formy przymiotnika, imiesłowy i formy bezosobowe czasowników, nieregularnie zaś - rzeczowniki, co wskazuje na gramatykalizację i szczególny status wyrażenia не судьба кому-л. Ponadto, uznaje się je za wyrażenie samodzielne i częściowo sfrazeologizowane, ponieważ nie jest negacją rzeczownika cyдьбa ani predykatu cydьбa, gdyż nie można go zastąpić w zdaniach formą cydьбa. Synonimiczne mu wyrażenie не суждено posiada swój wariant twierdzący суждено, natomiast не судьба

${ }^{4}$ Zarówno w polszczyźnie, jak i w ruszczyźnie leksemy dola і доля mają wspólny prasłowiański źródłosłów. Pochodzą od prasł. *dol'a - pierwotnie 'odcięta, odłupana część, kawałek czegoś', wtórnie - 'przeznaczona dla kogoś, należna komuś część czegoś, prawo do udziału', a także 'powodzenie lub niepowodzenie' (przy otrzymywaniu przeznaczonej, należnej części np. majątku, spadku), 'dobry lub zły los, przeznaczenie, stąd niedola' (Boryś, 2005, 118). Leksem dola w słowniku Doroszewskiego definiowany jest jako 'los przypadający komuś w udziale; położenie, stan, powodzenie', a sfrazeologizowana fraza rzeczownikowa dola i niedola, jako 'różne koleje losu, szczęście i nieszczęście'. 
używane jest najczęściej w formie zanegowanej (Апресян, 2008, 9-10). Stylistycznie to wyrażenie neutralne, z ciążeniem ku potoczności.

Wspólnym znaczeniem rosyjskich wyrażeń не судьба $X$ i не суждено $X$ jest 'событие $\mathrm{X}$ не происходит, потому что такова судьба', w którym część presupozycyjną stanowi informacja 'потому что такова судьба', asercyjną - 'Х не происходит' (Апресян, 2008, 11). Różnice między nimi ujawniają się w użyciu.

Pierwszą jest orientacja czasowa - w wyrażeniu не суждено neutralna i zorientowana przede wszystkim na retrospektywne konteksty narracyjne, por.: Овидию не суждено было вернуться, chociaż może też być zorientowana prospektywnie wobec momentu mówienia: Этим планам не суждено сбыться. Wyrażenie не судьба кому-л. w takich kontekstach występować nie może: *Овидию была не судьба вернуться на родину, *Похоже, мне не судьба будет поехать во Францию (Апресян, 2008, 12).

Jak dowodzi W. J. Apresjan, predykat не судьба кому-л. wykazuje złożoną orientację czasową, jednocześnie odsyła do dwóch zdarzeń z bliskiej przeszłości i z przyszłości. Referencyjny kontekst niedawnej przeszłości badaczka uznaje za kluczowy dla tego wyrażenia i będący przyczyną braku rezultatywnej interpretacji znaczenia, która jest właściwa jego synonimowi не суждено. Kontekst ten warunkuje specyficzną interpretacyjność wyrażenia. Chociaż nie posiada ono cech klasycznych czasowników interpretacyjnych, służy interpretacji, gdyż pewne fakty uznaje się za przejaw woli losu, sprzeciwiającej się zajściu jakiegoś zdarzenia w przyszłości. Wyrażeniu temu towarzyszą często interpretatory значит, видно itp. Badaczka wskazuje, że interpretacja faktu dopiero co zaszłego lub zaszłego w niedalekiej przeszłości jest sednem rosyjskiego не судьба, a zdarzenie w przyszłości może nawet być domyślne. W synonimicznym не суждено odwrotnie - w centrum znajduje się to zdarzenie, które nie mogło zaistnieć, dlatego nieprawidłowe jest na przykład: *Телефон пропал, значит не суждено (Апресян, 2008, 13-15).

Wewnętrzna negatywność predykatu не судьба кому-л. wynika z typu zdarzeń, które opisuje, oraz z większej częstotliwości użycia tego wyrażenia wobec $c y \partial b б a$, co podważa uznanie ich za parę antonimiczną podobną do суждено - не суждено. Не судьба кому-л. odnosi się tylko do zdarzeń pożądanych, не суждено - do pożądanych i niepożądanych, dlatego dziwne dla języka rosyjskiego są użycia: * Видно мне не судьба опоздать 
на поезд, *Не судьба мне погибнуть в этой войне (poprawne, gdyby śmierć była pożądana przez mówiącego). Wyrażenie не судьба кому-л., jak uważa W. J. Apresjan, zawiera pesymistyczną implikację pragmatyczną: 'плохих событий трудно избежать, а хорошие события чаще не происходят' (Апресян, 2008, 16).

Oprócz trzech omówionych lingwistka wyróżnia jeszcze dwa komponenty znaczenia pragmatycznego wyrażenia не судьба кому-л., а jego pełna eksplikacja przedstawia się następująco:

a) mówiący interpretuje zdarzenie z niedalekiej przeszłości jako znak tego, że los jest jemu przeciwny;

b) zdarzenie to jest pożądane dla mówiącego;

c) mówiący uważa, że zdarzenie nie może mieć miejsca, bo los jest mu przeciwny;

d) dlatego mówiący uważa, że nie ma sensu robić tego, co mogłoby sprawić, że zdarzenie to by zaistniało;

e) mówiący przyjmuje fakt, że zdarzenia tego nie będzie (Апресян, 2008, 16-17).

Dwa ostatnie komponenty odzwierciedlają ideę charakterystyczną dla kultury rosyjskiej - pasywność, pokorne godzenie się z losem jako siłą, nad którą człowiek nie ma władzy, której nie jest w stanie zmienić. Temu godzeniu się z losem towarzyszy ubolewanie nad tym, że pożądane zdarzenie nie nastąpi. Liczne konteksty użycia wyrażenia w pierwszej dekadzie XXI wieku, jak stwierdza badaczka, pokazują też swego rodzaju dewaluację pierwotnego znaczenia wyrażenia - jest ono odnoszone do zdarzeń codziennych, niepoważnych, lekkomyślnych, „lekkich”, a miejsce ubolewania zajmuje w nich ulga, że los zwalnia z konieczności działania. Mówiący pod niemożnością zmiany losu ukrywa w ten sposób swoją pasywność, por.: По лени решили - не судьба, пущай спартанцы растут (Апресян, 2008, 17). Ta dewaluacja jest przyczyną bardzo dużej częstotliwości użyć tego wyrażenia właśnie w mowie potocznej, stwierdza uczona.

Predykat не судьба кому-л. nie posiada synonimicznej, synkretycznej, zgramatykalizowanej i sfrazeologizowanej formy w polszczyźnie. W tekstach literatury klasycznej wyrażenie tłumaczone jest na język polski jako:

(1) Напужались... Елена Андреевна „одного часа, говорит, не желаю жить здесь... уедем да уедем... Поживем, говорит, в Харькове, оглядимся и тогда за вещами 
пришлем...”. Налегке уезжают. Значит, Марина Тимофеевна, не судьба им жить тут. Не судьба... Фатальное предопределение [А. П. Чехов, Дядя Ваня, 1896].

Strach ich ogarnął... Pani Helena powiada: ,ani godziny nie będę tutaj mieszkała... wyjeżdżać i wyjeżdżać... pomieszkamy w Charkowie, powiada, rozpatrzymy się i wtedy przyślemy po rzeczy..." Bez bagaży wyjeżdżają. To znaczy tak, Maryno, że nie sądzone im tu mieszkać. Nie sądzone... Fatalne zrządzenie losu [A. Czechow, Wujaszek Wania, przeł. J. Iwaszkiewicz, 1994].

(2) Она побледнела в свою очередь. Прочитав, она возвратила мне письмо дрожащею рукою и сказала дрожащим голосом, Видно мне не судьба... Родные ваши не хотят меня в свою семью. Буди во всем воля господня! Бог лучше нашего знает, что нам надобно [А. С. Пушкин, Капитанская дочка, 1836]

Zbladła po przeczytaniu i drżącymi rękami zwróciła mi list mówiąc drżącym głosem, Taki widać los... Rodzice pańscy nie chcą przyjąć mnie do rodziny. Bądź wola twoja, Panie! Bóg najlepiej wie, czego nam trzeba [A. Puszkin, Córka kapitana, przeł. T. Stępniewski, S. Pollak, 1949].

Słownik dwujęzyczny jako odpowiednik rosyjskiego не судьба кому-л. podaje tylko nie było sadzone komuś (WSRP 2, 553) ${ }^{6}$. Najbliższym synonimem tej polskiej frazy czasownikowej oznaczającej, że 'coś nie ominie kogoś, gdyż nie ma on wpływu na swoje przeznaczenie’, jest książkowa fraza: coś jest pisane komuś 'sytuacja, o której mowa, musi lub musiała zaistnieć niezależnie od woli ludzi, których ona dotyczy, gdyż, zdaniem mówiącego, decydują o tym jakieś siły nadprzyrodzone' (WSJP). Dalej w polu bliskoznaczności może znajdować się: coś jest dane komuś 'komuś udało się doświadczyć czegoś lub uczestniczyć w czymś' (WSJP). Analogiczne polskim konstrukcjom celownikowym z formą imiesłowową są rosyjskie: мне суждено, дано, предопределено, на роду написано (CPC), należące do zakresu pojęcia СУДЬБА. W przeciwieństwie do predykatu не судьба кому-л. wszystkie one posiadają warianty pozytywne i zanegowane: coś jest sadzone komuś - coś nie jest sadzone komuś; coś jest pisane komuś - coś nie jest pisane komuś; coś jest dane komuś - coś nie jest dane komuś. Konteksty użyć notowane w Narodowym Korpusie Języka Polskiego wskazują, że w zdaniach twierdzących sądzone zdarzenia mogą być pozytywne czy pożądane, bądź negatywne czy niepożądane, jak w przykładach:

${ }^{5}$ Национальный корпус русского языка.

${ }^{6} \mathrm{~W}$ najnowszym Wielkim słowniku rosyjsko-polskim (Wawrzyńczyk, Kuratczyk, Małek, Bartwicka, 2004) wyrażenie nie jest indeksowane. 
(3) W istocie było mu sądzone przeżyć własnego ojca tylko niecały rok.

(4) Nie umiem ci powiedzieć jak bardzo jestem rad! Pójdziesz ze mną. Widzę teraz, że było nam sądzone iść razem. Ruszamy we dwóch [...].

(5) Nie wiem, czy nie wytrzymał jego organizm, czy też było mu sądzone, ale fakt jest faktem, że człowiek nie żyje.

Użycia form przeczących wyrażenia odnoszą się tylko do zdarzeń pożądanych i oczekiwanych:

(6) Ponownie ubiegał się o mandat w 1964 r., ale i tym razem nie było mu sądzone przebywający na emigracji w Madrycie Juan Peron wezwał swoich zwolenników do bojkotu wyborów.

(7) To dopiero początek wiosny i wielu nie będzie sądzone przeżyć tego roku - beznamiętnie czyta lektor.

(8) Jeżeli przyjmiemy, że jest rzeczą wysoce prawdopodobną, iż naszej emigracji nie jest sądzone powrócić - w takim wypadku należy z powyższego twierdzenia wyciągnąć konsekwencje i poddać rewizji naszą dotychczasową postawę.

Dodatkowo świadczą o tym występujące w kontekstach komentarze przyrematyczne: niestety - wykładnik postawy emocjonalnej wskazujący, że mówiący wie, iż jest tak, jak mówi i wolałby, żeby tak nie było, oraz jednak, który jest wykładnikiem poprawności wnioskowania i zawiera w sobie element niezgodności rozważań z tym, co realnie następuje, por.:

(9) Niestety, nisza w odnowionej fasadzie, w której miała stanąć ikona, okazała się za mała. Aleksander Newski musiał na razie pozostać w cerkwi. - Nie było mu sądzone jeszcze tam być - skwitował Konstanty Marczyk.

(10) Wydawało się, że złapałem Pana Boga za nogi. Skończyłem studia z wyróżnieniem. Pracę znalazłem bez kłopotu. Znam biegle angielski. Komputer jest moim narzędziem pracy. Jednak nie było mi sądzone cieszyć się życiem. Kilka miesięcy temu lekarz stwierdził, że będę musiał zrezygnować z pracy zawodowej, bowiem zapadłem na nieuleczalną chorobę [B. Wiktorowska, Choroba przekreśliła karierę, „Gazeta Ubezpieczeniowa", 20.09.2000].

(11) Niestety nie było mi dane ukończenie tej „renomowanej” szkoły. Pan pedagog tak skutecznie znęcał się psychicznie, że w końcu zmusił mnie do przeniesienia się do liceum wieczorowego [Będę cię pytał... aż się rozpłaczesz, „Tygodnik Ciechanowski”, 24.09.2003].

Podawana przez słownik jako odpowiednik rosyjskiego не судьба кому-л. forma czasu przeszłego polskiego wyrażenia zawęża znaczenie jednostki polszczyzny i dostosowuje do wskazywania na zdarzenie przeszłe jednostki rosyjskiej. Nie wykazuje przy tym precyzyjności jednostki 
rosyjskiej, która odnosi się tylko do zdarzeń niedalekiej przeszłości. Analiza korpusu polskiego pokazuje jednak, że w polszczyźnie wyrażenie używane jest przede wszystkim w formie czasu przeszłego.

Drugi z polskich odpowiedników rosyjskiego predykatu не судьба комy-л. to fraza zdaniowa taki los:

(12) „Niech sobie szukają, mam to w nosie, mam to wszystko w nosie! - myślał buntowniczo. - Żyć się nie chce, taki los! ...” Żyć mu się nie chciało, fakt, niemniej jednak siedzenie na niewygodnej gałęzi staje się w końcu uciążliwe nawet dla najbardziej udręczonego chłopaka [M. Tomaszewska, Zorro, załóż okulary!, 2001].

(13) Zalałem sobie na czerwono koszulę, kamizelkę i spodnie od nowego garnituru, materiał był w smużki, wszystko do wyrzucenia, ale warto było. Odtąd praktykowałem, kiedy tylko miałem ochotę. Poszło raz, to i drugi pójdzie, trudno, taki los. Jedni są koneserami win lub sklejają modele samolotów, jeszcze inni zaliczają panienki [W. Chmielewski, Brzytwa, 2008].

W perspektywie chciał doczekać wymarzonej emerytury i wcale nie miał ochoty niepotrzebnie nadstawiać karku, chyba że rzeczywiście wszyscy, wtedy trudno, taki los. To był po prostu rozsądny program, niczego nadzwyczajnego od losu nie wymagał [A. Anonimus, Nie nadaje się, przecież to jeszcze szczeniak, 1999].

(14) ...cały w strzępach, Aleksander obok niego i mówił, że mu zimno. Wszystko nas ominęło. Stracone pokolenie, taki los, gęsty jak las, lost generation... To dopiero śmierdziele. A myśmy im wierzyli. Poskrob Amerykańca, a zobaczysz zasrańca [A. Stasiuk, Biały kruk, 1994].

(15) Wszyscy umarli. Jesteśmy nieżywi. Taki los. Takie rozporządzenie nieba. - Ja jeszcze żyję. Słyszysz, ojcze? Wróciłam do życia, choć już jedną nogą byłam po tamtej stronie. Chcę żyć krótki moment tak jak chcę, po swojemu, po mojemu [T. Konwicki, Bohiń, 1987].

Fraza stwierdza konieczność pogodzenia się z zaistniałym bądź mogącym zaistnieć stanem rzeczy, który wskazuje kontekst wyrażenia. Brak możliwości wpływu za ten stan rzeczy podkreślać mogą wyrażenia współwystępujące, jak co robić, por.:

(16) Jeśli Szatan - niech się dzieje, co chce. Pewnie, że się zmutuje, ale przez kilka dni będzie przynajmniej spokój. Jeśli ćpun - tylko go nastraszy. Fatalne ryzyko, ale co robić, taki los. Skoro Tamten siedzi w niebie i z nudów obgryza paznokcie [M. Sieniewicz, Czwarte niebo, 2003].

Jedyne, co człowiek może zrobić wobec zdarzeń, to pogodzić się $\mathrm{z}$ nimi. Jak trudne to zadanie, podkreślają często występujące w połączeniu z frazą zdaniową taki los wyrażenia funkcyjne, jak wykładnik rezygnacji trudno 'mówiący, mimo iż nie akceptuje jakiegoś stanu rzeczy w pełni, 
zgadza się z tym, że musi on istnieć/nastąpić' (WSJP). Forma taki, taka, takie tworzy liczne konstrukcje wyrażające rezygnację i akceptację stanu rzeczy, na który człowiek nie ma wpływu. Wyrażenie może być rozszerzone o wykładnik temporalny już, stwierdzający, że to, o czym mowa, można orzec za prawdziwie teraz, chociaż nadawca sądził, że będzie to możliwe później, por.:

(17) A pan? Pan dostanie części? - Ja to mam, jak to się mówi, ludzi, co wszystkiego dopilnują. Taka moja robota, ciężka, niewdzięczna, uwierzy pan, czasem z byle listonoszem bym się zamienił albo i z brukarzem. Ale trudno, taki los. Nie dla siebie przecie, że tak powiem: dla kraju, dla społeczeństwa. [W. Kowalewski, Excentrycy, 2007].

(18) Czy ta wieś tylko taka, czy taki już świat. Sami głupcy. - I nachylając się nad strapieniem wujka, spytał: - No, a podejrzewasz kogo? - Bo ja wiem, panie burmistrzu. Raz mi ten przychodzi do głowy, raz inny, ale nic pewnego [W. Myśliwski, Widnokrag, 1996].

(19) [...] po co Marzena ciągnie mnie do lokalu, którego była nadal formalną współwłaścicielką, tym bardziej że zdecydowała się przyjąć propozycję męża i sprzedać mu swoją połowę. Nie miałem innego wyjścia, jak dowiedzieć się tego na miejscu. Być może narażając własną skórę, ale taki już mialem fach [M. Bielecki, Siostra Komandosa, 1997].

Te same różnice, jakie występują między polską frazą taki los i rosyjskim не судьба кому-л., występują również między rosyjskim synonimem такая судьба і analizowanym predykatem, por.:

(20) Во что превратится твоя жизнь... - Значит, такая судьба... У Саши было спокойное, бесстрастное лицо. Как у Володьки [В. Токарева, Своя правда, „Новый Мир”, 2002].

(21) Он умирает один. Такая судьба. А ведь все могло быть иначе. С родными не так страшно [Е. Н. Крюкова, Яства детства, „Волга”, 2009].

Frazy taki los і такая судьба to wyrażenia konieczności pogodzenia się z niepożądanymi zdarzeniami losu wobec braku możliwości jego zmiany przez człowieka. Z konstatacji, że stan rzeczy jest taki i nie można go zmienić, wynika zalecenie pogodzenia się, zaakceptowania go.

Status rosyjskiego wyrażenia не судьба кому-л. jako jednostki silnie nacechowanej kulturowo jest niepodważalny. Istniejące w polszczyźnie synonimiczne jednostki językowe coś nie było sądzone komuś i taki los wykazują różnice zarówno w warstwie znaczeniowej, jak i pragmatycznej.

Wspólnymi elementami znaczeniowymi не судьба кому-л. і соś nie byto sądzone komuś są: 
a) mówiący interpretuje zdarzenie jako znak tego, że los jest jemu przeciwny;

b) zdarzenie to jest pożądane dla mówiącego;

c) mówiący uważa, że zdarzenie nie może mieć miejsca, bo los jest mu przeciwny;

d) dlatego mówiący uważa, że nie ma sensu robić tego, co mogłoby sprawić, że zdarzenie to by zaistniało;

e) mówiący przyjmuje fakt, że zdarzenia tego nie będzie.

Polskie wyrażenie coś nie było sądzone komuś nie wykazuje cech dewaluacji pierwotnego znaczenia i ciążenia ku potoczności.

Frazę zdaniową taki los charakteryzują następujące elementy:

a) mówiący interpretuje zaistniałe zdarzenie jako znak tego, że los jest jemu przeciwny;

b) zaistniałe zdarzenia są dla mówiącego niepożądane;

c) mówiący uznaje, że nie może nic zrobić, by zmienić to, co zaistniało;

d) mówiący przyjmuje zaistniały fakt.

Wspólnymi komponentami znaczeniowymi jest uznanie, że los jest człowiekowi przeciwny, zaistniałe zdarzenia nie były przez człowieka pożądane czy nie są pozytywne, a wobec niemożności zmiany tego stanu rzeczy przyjmuje je. Wielki słownik języka polskiego odnotowuje potoczne wyrażenie taka już czyjaś uroda, oparte na konstrukcji taki_taki już, w której godzenie się z istniejącym stanem rzeczy nie wiąże się z ubolewaniem, a fraza nosi cechy „lekkości”, podobne jak „lekkość” zdarzeń i postawy wobec nich, stwierdzana przez W. J. Apresjan w najnowszych użyciach predykatu не судьба кому-л. I ta polska jednostka zdaje się najlepiej oddawać potoczne znaczenie tego rosyjskiego predykatu: По лени решили - не судьба, пущай спартаниы растут - por.: Z lenistwa to zrobili, nie było im sadzone, niech rosna Spartanie; Z lenistwa to zrobili, taki los, niech rosna Spartanie; $Z$ lenistwa to zrobili, taka ich uroda, niech rosna Spartanie.

Ideą charakterystyczną kultury rosyjskiej, podkreśla W. J. Apresjan, jest pasywność, pokorne godzenie się z losem. Na pesymizm, pasywność i pokorę w przyjmowaniu zdarzeń w pojęciu СУДЬБА zwracała zaś uwagę A. Wierzbicka. Polskie odpowiedniki wyrażenia не судьба кому-л. - соś nie było sądzone komuś i taki los również zawierają znaczenie godzenia się z losem, jednakże podkreślana przez badaczy rosyjska inercja wobec losu może wynikać ze związku pojęcia СУДЬБА z pojęciem $S A D D$, a nie jak 
w polszczyźnie ze sferą działań magicznych i pojęciem LOTERII. Jak pokazują polskie słowniki ${ }^{7}$, akt godzenia się z czymś może przebiegać jako aktywny proces przejścia od buntu wobec czegoś do jego akceptacji albo bierne poddanie się. Wpisana w analizowane pojęcia rosyjska pasywność w odróżnieniu od polskiej aktywności jest odzwierciedleniem szerszych zjawisk związanych z mentalnością obu narodów.

\section{Literatura}

Bańkowski, A. (2000). Etymologiczny słownikjęzyka polskiego, t. 1-2. Warszawa: Wydawnictwo Naukowe PWN.

Bartmiński, J. (2000). Polska 'dola' - rosyjska 'sud'ba'. „Etnolingwistyka” 12, s. 25 -37 .

Boryś, W. (2005). Stownik etymologiczny języka polskiego. Kraków: Wydawnictwo Literackie.

Długosz-Kurbaczowa, K. (2008). Wielki stownik etymologiczno-historyczny języka polskiego. Warszawa: Wydawnictwo Naukowe PWN.

Doroszewski, W. (red.). (1955-1969). Słownik języka polskiego. Warszawa: Państwowe Wydawnictwo Naukowe. https://sjp.pwn.pl/doroszewski/lista. 10.06.2020.

Duden 7 - Drosdowski, G., Grebe, P. et al. (1963). Etymologie. Herkunftswörterbuch der deutschen Sprache. Mannheim-Wien-Zürich: Dudenverlag.

Narodowy Korpus Języka Polskiego 2008-2012. Instytut Podstaw Informatyki PAN, Instytut Języka Polskiego PAN, Wydawnictwo Naukowe PWN, Zakład Językoznawstwa Komputerowego i Korpusowego Uniwersytetu Łódzkiego. http://www. nkjp.pl. 12.06.2020.

Hordy, М. (2020 [w druku]). Русский авось и его польские параллели. W: Contributions to the $23^{\text {rd }}$ Annual Scientific Conference of the Association of Slavists (Polyslav). Wiesbaden, 125. (Die Welt der Slaven. Sammelbände/Сборники). Eds K. Bednarska, D. Kruk, B. Popov, O. Saprikina, T. Speed, K. Szafraniec, S. Terekhova, R. Tsonev, A. Wysocka. Wiesbaden: Harrassowitz Verlag, s. 125-132.

SWJP - Dunaj, B. (1996). Słownik współczesnego języka polskiego. Warszawa: Wydawnictwo Wilga.

${ }^{7}$ Por. znaczenie godzić się I - 'przestawać buntować się przeciw czemu, przyjmować coś z rezygnacją; oswajać się z czymś’: Powoli godzi się z myśla o kalectwie. Pogodził się z utrata przyjaciela i godzić się II - 'pozwalać na coś, przyjmować bez zastrzeżeń; wyrażać zgodę na coś' (SWJP, 279-280). W najnowszym słowniku polszczyzny występuje zaś tylko jedno znaczenie czasownika w odniesieniu do argumentów nieożywionych: 2. 'biernie poddać się czemuś niekorzystnemu', synonimiczne poddać się, np.: pogodzić się z chorobą, kalectwem; klęską, porażką; stratą; czyimś odejściem; śmiercią; losem, przeznaczeniem; przemijaniem; z myślą o czymś; z jakimś faktem; trudno pogodzić się z czymś (WSJP). 
Wierzbicka, A. (1991). Język i naród: polski los i rosyjska sud'ba. „Teksty Drugie” 3 (9), s. 5-20.

WSJP - Żmigrodzki, P. (red.) (2007-). Wielki słownik języka polskiego. Kraków: Instytut Języka Polskiego PAN. http://www.wsjp.pl. 23.06.2020.

WSRP - Mironowicz, A., Dulewiczowa, I., Grek-Pabiasowa, I. et al. (1993). Wielki słownik rosyjsko-polski. Warszawa: Wiedza Powszechna.

Wawrzyńczyk, J., Kuratczyk, M., Małek, E., Bartwicka, H. (2004). Wielki słownik polsko-rosyjski PWN. Warszawa.

Апресян, В. Ю. (2006). Семантика и прагматика судьбы. W: Компьютерная лингвистика и интеллектуальные технологии. Труды международной конференциии „Диалог 2006”. Red. Н. И. Лауфер, А. С. Нариньяни, В. П. Селегея. Москва: Изд-во РГГУ, s. 31-37.

Апресян, В. Ю. (2008). О судьбе и не-судьбе. W: Динамические модели. Сборник статей в честь E.B. Падучевой. Москва: Языки Славянских Культур, s. 7-19. Апресян, Ю. Д. (2006а). Основания системной лексикографии. W: Языковая картина мира и системная лексикография. Москва: Языки славянских культур, s. 33-161.

Арутюнова, Н. Д. (red.) (1994). Понятие судьбы в контексте разных культур. Москва: Наука.

Булыгина, Т. В., Шмелёв, А. Д. (1997). Языковая концептуализация мира (на материале русской грамматики). Москва: Школа „Языки русской культуры”.

Вежбицка, А. (1994). Судьба и предопределение. „Путь. Международный философский журнал" 5, s. 82-150.

Национальный корпус русского языка. https://ruscorpora.ru. 23.06.2020.

СРС - Абрамов, Н. (1999). Словарь русских синонимов и сходных по смыслу выражений. Москва: Русские словари. http:/gramota.ru/slovari/info/abr/. 26.04.2020.

Цветаева, М. (1937). Повесть о Сонечке. https://www.100bestbooks.ru/read book. php?item_id=8853\&page=5. 10.04.2020.

Шмелёв, А. Д. (2002). Русский язык и внеязыковая действительность. Москва: Языки славянской культуры.

[Apresân, V. Û. (2006). Semantika i pragmatika sud'by. W: Komp'ûternaâ lingvistika i intellektual'nye tehnologii. Trudy meždunarodnoj konferencii „Dialog 2006”. Red. N.I. Laufer, A. S. Narin’âni, V. P. Selegeâ. Moskva: Izd-vo RGGU, s. 31-37.

Apresân, V. Û. (2008). O sud'be i ne-sud'be. W: Dinamičeskie modeli. Sbornik statej v čest' E. V. Padučevoj. Moskva: Âzyki Slavânskih Kul'tur, s. 7-19.

Apresân, Û. D. (2006a). Osnovaniâ sistemnoj leksikografii. W: Azykovaâ kartina mira i sistemnaâ leksikografiâ. Moskva: Âzyki slavânskih kul'tur, s. 33-161.

Arutûnova, N. D. (red.) (1994). Ponâtie sud'by v kontekste raznyh kul'tur. Moskva: Nauka.

Bulygina, T. V., Šmelëv, A.D. (1997). Azykovaâ konceptualizaciâ mira (na materiale russkoj grammatiki). Moskva: Škola „Âzyki russkoj kul'tury”. 
Vežbicka, A. (1994). Sud'ba i predopredelenie. „Put'. Meždunarodnyj filosofskij žurnal" 5, s. 82-150.

Nacional'nyj korpus russkogo âzyka. https://ruscorpora.ru. 23.06.2020.

SRS - Abramov, N. (1999). Slovar' russkih sinonimov i shodnyh po smyslu vyraženij. Moskva: Russkie slovari. http://gramota.ru/slovari/info/abr/. 26.04.2020.

Cvetaeva, M. (1937). Povest' o Sonečke. https://www.100bestbooks.ru/read_book. php?item_id=8853\&page=5. 10.04.2020.

Šmelëv, A. D. (2002). Russkij âzyk i vneâzykovaâ dejstvitel'nost'. Moskva: Âzyki slavânskoj kul'tury]. 